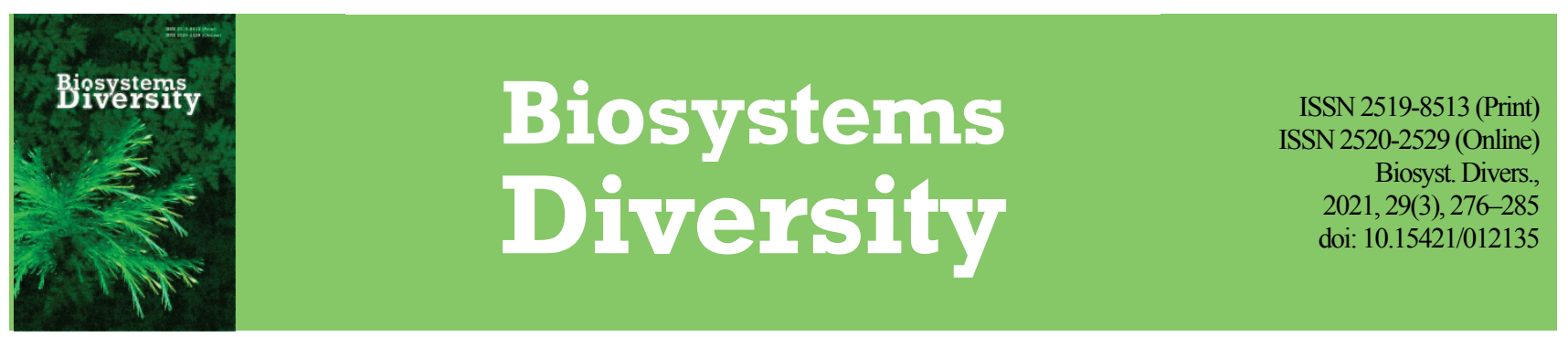

\title{
Phytoindication assessment of the effect of reconstruction on the light regime of an urban park
}

\author{
O. M. Kunakh*, O. I. Lisovets****, N. V. Yorkina***, Y. O. Zhukova* \\ * Oles Honchar Dnipro National University, Dnipro, Ukraine \\ **Dnipro State Agrarian and Economic University, Dnipro, Ukraine \\ ***Bogdan Khmelnitsky Melitopol State Pedagogical University, Melitopol, Ukraine
}

Article info

Received 22.07.2021

Received in revised form 23.08.2021

Accepted 25.08.2021

\author{
Kunakh, O. M., Lisovets, O. I., Yorkina, N. V., \& Zhukova, Y. O. (2021). Phytoindication assessment of the effect of reconstruction on \\ the light regime of an urban park. Biosystems Diversity, 29(3), 276-285. doi:10.15421/012135
}

Oles Honchar Dnipro

National University,

Gagarin av., 72

Dnipro, 49000, Ukraine.

Tel.: +38-098-858-23-79.

E-mail:kunah_olga@ukr.net

Dnipro State Agrarian

and Economic University,

Sergey Efremov st., 25 ,

Dnipro, 49600, Ukraine

Tel.: +38-050-421-69-69.

E-mail:

lisovetselena@gmail.com

Bogdan Khmelnitsky

Melitopol State Pedagogical

University, Hetmanska st., 20

Melitopol, 72318, Ukraine.

Tel.: +38-068-154-15-78

E-mail:

nadyayork777@gmail.com

The ecological restoration of urban parks is used to increase their recreational attractiveness, improve air quality, mitigate urban heat island effects, improve stormwater infiltration, and provide other social and environmental benefits. The dynamics of plant communities after urban forest restoration requires investigation. The study assessed the impact of urban park reconstruction on the state of grass cover, phytoindication of changes in light regime caused by park reconstruction and found out the dependence of reliability of phytoindication assessment on the number of species in the relevant area. The study was conducted in the recreational area of the Botanical Garden of the Oles Honchar Dnipro National University (Ukraine). A tree plantation was created after the Second World War in the location of a natural oak forest. In 2019, a 2.8 ha area of the park was reconstructed. The samples were taken within polygons, two of which were placed in the reconstruction area and two of which were placed in a similar section of the park where no reconstruction was performed. During the reconstruction process, walkways were rebuilt, shrubs were removed, old, damaged trees were removed, and tree crowns were trimmed. Juvenile trees were planted in place of the removed old trees. Old outbuildings, which greatly impaired the aesthetic perception of the park, were also removed. Transport and construction machinery was involved in the reconstruction. A total of 65 plant species were found within the studied polygons. The number of herbaceous species in the park area after reconstruction was higher than without reconstruction. The crown closure in the reconstructed area was significantly lower than that in the untreated conditions. The phytoindication assessment showed that the light regime varies from the conditions suitable for the scyophytes (plants of typical foliage forests) to the conditions suitable for the sub-heliophytes (plants of light forests and shrubberies, or high herbaceous communities; lower layers are in the shade). The light regime in the park area after reconstruction was statistically significantly different from the regime in the untreated park area. The lighting regime after the reconstruction was favourable to sub-heliophytes, and without reconstruction the regime favoured hemi-scyophytes. Tree canopy crown closure negatively correlated with grass height and herbaceous layer projective cover. The tree canopy crown closure, grass height, and herbaceous layer projective cover were able to explain $86 \%$ of the phytoindication assessment of the lighting regime variation. These parameters negatively affected the light regime. The prospect of further research is to investigate the dependence of indicative reliability of the assessment of other environmental factors with the help of phytoindication depending on the number of species. In addition to the indication of traditional ecological factors it is of particular interest to clarify the aspect of the dynamics of hemeroby indicators as a result of park reconstruction.

Keywords: recreation; diversity; indicator reliability; hemeroby; ecosystem transformation; plant community.

\section{Introduction}

The factors that affect plant communities vary depending on the hierarchical scale of the study (Gaujour et al., 2012; Angeler et al., 2013). At the global and continental level, the species richness of plant communities is mainly influenced by climatic factors (Currie, 1991; Wamelink et al., 2003; Xu et al., 2016). At the regional level, in addition to climatic factors, relief effects and landscape diversity become important (Isbell et al., 2017; Putchkov et al., 2019; Harrison, 2020). The factors determining species richness vary by region. Elevation range and net primary productivity are important predictors of plant community diversity. Also, elevation range is positively related to plant species richness. This indicates that elevation range often becomes the dominant controlling factor in regions with sufficient energy (Xu et al., 2016). At the same time, the role of ecological features of individual plant species and their assemblages, as well as the peculiarities of their evolutionary history, is increasing. On the local scale, climatic factors are of secondary importance due to their small spatial variations within the study areas. However, on the local scale, the habitat characteristics such as topography, light exposure, tree crown cover, and soil properties attract special attention (Brygadyrenko, 2015; Samec et al., 2021). The light condition is important for ecology of forest and park plantations (Jennings, 1999). Solar radiation in the form of light is a leading factor in many biological, ecological, physiological, and hydrological processes (Van der Zande et al., 2011; Zhukov et al., 2021). The undergrowth light environment is a key determinant of vegetation structure and ecosystem processes, and varies spatially perhaps more than any other resource used by plants. The light exposure of undergrowth varies along vegetation structure gradients from a grassland with no tree cover to a forest with nearly complete tree cover (Martens et al., 2000). Radiation in forest and park stands affects photosynthesis, transpiration, vegetation structure (Peng et al., 2014), stand development dynamics (Zavala et al., 2007), tree plant growth (Grant, 1997), and production efficiency (Englund et al., 2000). Significant positive correlations were found between incident solar energy and aboveground biomass in forest ecosystems (Zavitkovski, 1976). The influence of solar radiation also manifests in the forest litter (Maltsev et al., 2017; Tudoroiu et al., 2018). Light passing through canopy affects germination and growth of understory (Anderson \& Denmead, 1969; Grant, 1997; Kyereh et al., 1999), regeneration and succession (Sakai \& Akiyama, 2005; Van der Zande et al., 2010), soil condition (Von Arx et al., 2012; Musselman et al., 2013), and biodiversity (Battisti et al., 2013; Sercu et al., 2017; Chaplygina et al., 2018; Tsai et al., 2018). The light regime in forest and park plantations 
depends on canopy structure, site characteristics, atmospheric conditions, and sun altitude (Jones et al., 2003; Alexander et al., 2013; Bode et al., 2014; Brygadyrenko, 2016). These factors create a complex light pattern of the undergrowth, which expresses not only in horizontal heterogeneity, but also vertical variation at any given time (Peng et al., 2014).

The vegetation is able to improve the urban microclimate through shading (Bartels \& Chen, 2010; Adler et al., 2011; Li et al., 2018; Storch et al., 2018) and by evaporation (Dimoudi \& Nikolopoulou, 2003; Georgi \& Dimitriou, 2010; Duarte et al., 2015). In turn, the urban vegetation may adapt to climate change itself (Hamada \& Ohta, 2010). Urban trees can compensate or reverse the effects of heat islands. Mitigating the effects of urban heat islands has the potential to reduce energy use for air conditioning and improve urban air quality (Akbari et al., 2001). Influencing the microclimate with plants can improve the comfort of the city population (Lin et al., 2010; Shahidan et al., 2010). The air temperature in the shade of trees in summer is significantly lower than in areas without trees. Multilevel plant communities are the most effective in terms of their cooling and moisturizing effect (Zhang et al., 2013). The planting of grass in combination with shade trees can have a pronounced effect on the reduction of air temperature (Shashua-Bar et al., 2010). The structural characteristics of urban green space plant communities are important factors in mitigating the effects of heat. The cooling and moisturizing effects are controlled by canopy density, leaf area index and average leaf angle (Qin et al., 2014), as well as canopy density, canopy area, tree height, and solar radiation (Zhang et al., 2013). There are many factors that can influence the attractiveness of urban parks to residents, including features of plant community structure (Xue et al., 2017b, 2017a; Zhukov et al., 2021). The density and light regime of park stands influenced the degree to which parks were preferred by different resident groups. Moderately dense plantings were the most preferred. A curvilinear effect of respondents' age on preference for moderately and densely vegetated scenes was found. Respondents in their early 40 s expressed the greatest preference for moderate and dense vegetation compared to younger and older respondents. The preference for moderate and dense vegetation also increased as respondents' level of education increased (Bjerke et al., 2006). Separate physical attributes have no predictive power to explain residents' preferences for particular environmental conditions. Perception-based variables proved to be the most effective, with parkland openness and soil surface smoothness proving to be particularly useful predictors (Kaplan et al., 1989; Strumse, 1994b, 1994a). Forest patches with dense vegetation support a diversity of wildlife habitats. On the other hand, the aesthetic quality of the natural environment is associated with more open grassy areas, where random groups of trees and shrubs are represented (Parsons, 1995). The structural characteristics of plant communities affect the ability to mitigate the thermal environment and influence the perceived suitability of park areas for outdoor recreation (Li et al., 2018; Dormann et al., 2020).

Urban habitats differ notably in the diversity of their vascular plant flora (Lososová et al., 2011; Shekhovtseva \& Mal'tseva, 2015). Socioeconomic, environmental, and conservation factors influence the diversity and composition of plant communities in urban parks (Figueroa et al., 2018). Anthropogenic impacts alter the structural development of urban forests, affecting both positively through the formation of gaps, the appearance of deadwood, and the formation of ecosystem complexity, and negatively through the shifts in composition and successional trajectories (Alasmary et al., 2020; Matsala et al., 2021). Plants are an important component of landscape design (Maltsev \& Maltseva, 2018; Goncharenko \& Yatsenko, 2020). They perform a number of functions in a holistic landscape (Maltseva et al., 2017). Landscaping projects focus on the importance of plants in improving ecology and the environment. A park reconstruction allows space to be created for plants without altering the original ecological environment in the park, thereby achieving an optimal visual experience for tourists $(\mathrm{Li}, 2020)$. The individual plants are sensitive to a variety of environmental properties and thus can be indicators of the ecological factors. The sensitivity of an individual species to the action of environmental factors can vary according to Shelford's law of tolerance (Shelford, 1931), so a reliable assessment of environmental properties can be made on the basis of studying the species composition of the plant community. Phytoindication methods based on Ellenberg indicator values (EIVs) (Ellenberg, 1979) or Didukh (Didukh, 2011) are often used to assess habitat conditions. The indicator scales can be ranges (Didukh, 2011) or such that indicate the ecological optimum of the species (Ellenberg, 1979). In the Ellenberg system, the ecological optimums of individual plant species are expressed in the form of ordinal numbers. The average values of Ellenberg indices calculated for vegetation sites make it possible to estimate specific habitat conditions (Diekmann, 2003). To assess the properties of the environment using the range scales of Didukh (Didukh, 2011), either the weighted average method (Didukh, 2011) or the ideal indicator method (Buzuk, 2017) is used. Using phytoindication as a surrogate for directly measured environmental variables saves time and reduces research costs (Dzwonko, 2001). Numerous studies confirm the usefulness and validity of the phytoindication method. The correlations between phytoindication estimates of environmental properties and the results of physical and chemical field measurements were proven (Ellenberg et al., 1991; Diekmann, 1995; Ertsen et al., 1998; Schaffers \& Sýkora, 2000). Nevertheless, there are also problems associated with the use of indicator analyses. Statistical inferences should not be made in analyses that relate phytoindicator values to other variables derived from species composition, as this can lead to highly biased results and misinterpretations (Zelený \& Schaffers, 2012; Wildi, 2016). The phytoindicator scales demonstrate the maximum effectiveness in studies on large temporal or spatial scales (Pignatti et al., 2001). There are few studies on the relationship between the morphological properties of plants and indicator scale values of light (L-numbers). A study on annual weeds showed a significant negative correlation of seed weight with L-numbers. In annuals, heavier seeds are more common in species from more shady habitats. A likely advantage of this may be stronger support for germinating seeds when energy requirements cannot be satisfied by photosynthesis alone (Bartelheimer \& Poschlod, 2016). The L-numbers of perennial grasses negatively correlated with germination rate (Grime et al., 1981). A possible biological explanation could be that high-intensity habitats are prone to drought, so slow germination increases the risk of desiccation (Bartelheimer \& Poschlod, 2016). There are few studies on the relationship between light indicator values and light intensity in forests. The values of this indicator are good predictors of relative light intensity in deciduous forests (Diekmann, 1995; Dzwonko, 2001). The positive correlation of indicator values of temperature and light with the average annual temperature was explained by the adaptation of heliophilous species to locations where the high temperatures are always associated with intense solar radiation (Marcenò \& Guarino, 2015).

The phytoindication approach was shown to be effective in assessing the impact of silvicultural practices on ecological regimes (Hannerz \& Hånell, 1997). Phytoindication method is applied to assess ecological lands for the conservation of vascular plant diversity in urban environments (Zhukov et al., 2017; Dyderski et al., 2017). According to the mean Ellenberg indicator values calculated for the five land use types within urban environments, densely built-up areas were characterized by higher light availability, soil nutrients, soil $\mathrm{pH}$, and lower soil moisture compared with open built-up areas (Godefroid \& Ricotta, 2018). Anthropogenic parts of cities are typically dry (Grimm et al., 2008), unshaded (Chocholoušková \& Pyšek, 2003), and dominated by building materials that tend to be highly alkaline (Deutz et al., 2017). Environmental conditions, as determined by Ellenberg values, were found to be similar for areas of dense development and industrial zones (Godefroid \& Ricotta, 2018). In Europe, a shift in the structure of urban plant communities toward shade-tolerant species has been occurring over the past 120 years. This trend was revealed by means of Ellenberg indicator values analysis. Such trends are mainly due to an increase in the number of parks and trees in urban areas. The climate change and the presence of artificially irrigated areas in the city led to an increase in hygrophilous and drought-tolerant species. The temperature index showed a significant increase in the number of macrothermal species that are adapted to a warmer climate as a response to the urban heat island effect (Salinitro et al., 2019). Ellenberg's indicator values revealed that since 1940, the flora of the Brussels region has become more nitrophilic and shade-tolerant, with changes in relation to moisture and soil reaction as well as temperature (Godefroid, 2001).

Municipalities use ecological restoration of urban forests as a measure to improve air quality, mitigate urban heat island effects, improve stormwater infiltration, and provide other social and environmental benefits. 
However, the dynamics of plant communities following urban forest restoration are poorly documented. The objectives of this study were to: (1) evaluate the impact of urban park reconstruction on the condition of herbage cover; (2); perform the phytoindication of changes in the light regime caused by the reconstruction of the park and (3) to find out the dependence of reliability of phytoindication estimation on the number of species in the relevé.

\section{Materials and methods}

Study area. The study was conducted in the recreational area of the Botanical Garden of Oles Honchar Dnipro National University (Ukraine). The tree plantation was created after the Second World War in the location of a natural oak forest. In 2019, a 2.8 ha area of the park was reconstructed. The samples were taken within polygons, two of which were in the reconstruction area and two of which were in a similar section of the park where no reconstruction was performed. During the reconstruction, walkways were rebuilt, shrubs were removed, old, damaged trees were removed, and tree crowns were trimmed. Juvenile trees were planted in the places of the removed old trees. Old outbuildings, which greatly impaired the aesthetic perception of the park, were also removed. Transport and construction machinery was involved in the reconstruction. The works were carried out during the warm period of the year.

Data collection. Each polygon consisted of 105 sample points. The points were located along 7 transects with 15 sample points in each. The distance between points in the transects, as well as the distance between transects, was $3 \mathrm{~m}$. The adjacent sample points were in close proximity to each other. The vascular plant species lists were composed for each $3 \times 3 \mathrm{~m}$ sample point along with a visual assessment of species cover using the nine-degree Braun-Blanquet scale (Westhoff \& Van Der Maarel, 1978). The projective cover of plant species was recorded at soil, understory (up to $2 \mathrm{~m}$ in height), and canopy (above $2 \mathrm{~m}$ in height) levels. The species were all identified to species level in all plots. The seedlings and saplings of tree species were subsequently excluded from the analysis.

Phytoindicator procedure. The scales were used for phytoindication according to Didukh (2011). Species live along environmental gradients. The distribution of a species along a gradient is known as a response curve. The concept of the species response curve is the theoretical basis for the development of phytoindication approaches (Didukh, 2012). The conceptual form of the response curve is traditionally thought to be unimodal and symmetric (bell-shaped or Gaussian) (ter Braak \& Looman, 1986), but various other forms of response curves can be observed (Huisman et al., 1993; Lawesson \& Oksanen, 2002). The actual distributions of species are most often asymmetric, so they cannot be described by a Gaussian distribution (Austin et al., 1994). The asymmetric distributions of species are extremely common. The tails of the distributions tend to be directed toward more favourable values of environmental factors (Austin et al., 1990; Austin, 2013). The asymmetric nature of species distributions requires adjustments to the procedure of determining the species optimum as an indicator value for evaluating environmental properties. To model the response function of species in a gradient of environmental conditions, a $\beta$-function was proposed (Austin, 1976; Austin et al., 1994):

$$
V=k \times(x-a)^{\alpha} \times(x-b)^{\prime},
$$

where $\mathrm{V}$ is a measure of the species abundance; $\mathrm{k}$ is a constant; $\mathrm{a}$ and $\mathrm{b}$ indicate the smaller and larger boundary of the species in the gradient of variable $\mathrm{x} ; \alpha$ and $\gamma$ are distribution shape parameters. In the range of values of $a$ and $b$, the $\beta$-function can exhibit a considerable variety of possible shapes of distributions from a close approximation of the Gaussian distribution to a highly asymmetric distribution. To solve the problem in general form, the analytical representation of the $\beta$-function could be simplified by setting the dependence of the unknown shape indices $\alpha$ and $\gamma$ on the known parameters a and $b$ (Zhukov et al., 2018). Then the function takes the following form:

$$
V=k \times(x-a)^{a} \times(x-b)^{1-b},
$$

where $\mathrm{x}$ is normalized to range $0-1$. For the case where $\mathrm{a}=1-\mathrm{b}$, the $\beta$ function will be symmetric. For the case where $\mathrm{a}=0$ or $\mathrm{b}=1$, the maximum of the function will be either at $\mathrm{x}=0$ or $\mathrm{x}=1$, respectively. For transient values of $a$ and $b$, the $\beta$-function is asymmetric and gradually shifts between the two extremes of the distribution (Zhukov et al., 2018). In the equation, the parameter $\mathrm{k}$ has the character of normalization coeffi- cient. At the point of optimum, the index of species abundance reaches the highest value of 1 (or 100\%). At least one species in the community can be assumed to be under optimal conditions and to be dominant. Therefore, the abundance index of the dominant species (projective cover, crown density, number of shoots) can be taken as the maximum $100 \%$ in the community among all plants of the same layer. The relative abundance of a species in the community can be estimated as the ratio of the observed abundance of a species $(\mathrm{p})$ to the abundance of the dominant species $\left(\mathrm{p}_{\max }\right)$ within a layer: $\mathrm{p} / \mathrm{p}_{\max }$. The information about the abundance of a species in a community greatly increases its phytoindication value. If the response function of the species is estimated, the abundance of the species in the community significantly narrows the range of conditions that can respond to the observed abundance index. The phytoindication scales were normalized to the range of $0-1$. The distribution of plant projective cover along the ecological factor gradient was modeled using beta function. The range scales values according to Didukh (2011) were used as the threshold values of the function. Thus, modeling the response of species along the environmental factor gradient made it possible to recalculate "tabular" values of the range phytoindication scale into new local scales that account for species abundance in a particular community. Further, for the purpose of phytoindication of environmental factors, we used the ideal indicator method of Buzuk (2017). This approach is based on the assumption that ecological conditions can be most accurately indicated by a species with zero tolerance, i.e., a species whose minimum and maximum threshold points coincide. Obviously, no such species exists, but the properties of the ideal indicator can be calculated by determining the dependence of the upper and lower threshold values on the tolerance index, which is the difference of these upper and lower threshold values. The regression dependences for both the maximum threshold value and the minimum threshold value on tolerance pass through the same point on the ordinate axis, which corresponds to zero tolerance. Such a situation corresponds to a hypothetical species that can inhabit only a given habitat with an appropriate ecological regime. This virtual species is the ideal indicator. The original ideal indicator procedure does not take into account species abundance. Our methodology does not use "tabulated" values of threshold points, but rather recalculated with taking into account species abundance.

Permutation test. The estimation of phytoindication parameters can be carried out for objects of different dimensions. As the area of the object under study increases, the number of species naturally increases and thus, the accuracy of phytoindication assessment increases. However, such estimation is accurate for the whole studied area, but there is no reason to believe that it is valid for each individual site within the studied area. Reducing the sample area decreases the number of species in the description, and thus the accuracy of the estimate, but the resolution of the method increases. To the data we obtained, we applied the permutation method, which allowed us to estimate the probability of difference between the phytoindicator estimates in a given site and the values of environmental factors estimated based on a random sample of species from the list of all species that occur in the polygon. Note that the standard permutation test procedure uses null distribution created by calculating the test statistics using randomized data. To account for the similarity problem, a modification of this first step has been proposed, the specificity of which is that the test statistic is calculated not using randomized averages of the real indicator values, but using (non-randomized) mean randomized indicator values instead (i.e., randomizing the species indicator values among the species in the table instead of randomizing the calculated averages) (Zelený \& Schaffers, 2012). The feature of our variant of the permutation procedure is that the null distribution is generated by randomly choosing species from the list of species for the polygon, rather than by randomly choosing indicator values that occur in species within the same polygon. The experimental value of the statistics and the values of the randomly generated sample were compared using the as.randtest function from the ade4 library (Dray \& Dufour, 2007).

\section{Results}

A total of 65 plant species were found within the studied polygons. The phanerophytes were represented by 11 species, the nonphanerophytes were represented by two species, the hemicryptophytes were represented 
by 29 species, the therophytes were represented by 16 species, and the geophytes were represented by 7 species. At each individual site, the number of species in the herb layer ranged from 5 to 19 (Table 1). Differences between the polygons in the number of herbaceous species in the individual site were statistically significant $(\mathrm{F}=53.5, \mathrm{P}<0.001)$. The number of herbaceous species in the park area after reconstruction was higher compared to the unreconstructed area $(\mathrm{F}=119.7, \mathrm{P}<0.001)$. Tree canopy crown closure varied widely, from $0 \%$ to $95 \%$. The differences in this indicator between the polygons are statistically significant $(\mathrm{F}=381.7, \mathrm{P}<$ $0.001)$. The crown closure in the reconstructed area was significantly lower than such in the untreated conditions $(\mathrm{F}=90.8, \mathrm{P}<0.001)$. The polygons in the reconstruction zone (polygon 1 and 2) did not differ from each other in terms of crown cover (planned comparison $\mathrm{F}=0.38$, $\mathrm{P}=0.55$ ). The polygon 4 had significantly more crown closure than polygon 3 in the untreated conditions (planned comparison $\mathrm{F}=191.5, \mathrm{P}<$ $0.001)$.

The grass height on average was $0.60 \pm 0.01 \mathrm{~m}$. The differences in grass height between the polygons were statistically significant $(F=107.9$, $\mathrm{P}<0.001$ ). The grass height in the reconstruction zone was higher than without reconstruction $(\mathrm{F}=26.1, \mathrm{P}<0.001)$. The average projective cover of the grass was $66.9 \pm 1.0 \%$. The differences between the polygons in projective grass cover were statistically significant $(\mathrm{F}=58.1, \mathrm{P}<0.001)$. The differences between the zones after and without reconstruction were statistically insignificant $(\mathrm{F}=1.53, \mathrm{P}=0.21)$.

The phytoindication assessment showed that the light regime varied 3.8 (the conditions suitable for the scyophytes - plants of typical foliage forests) to 8.75 (the conditions suitable for the sub-heliophytes - plants of light forests and shrubberies, or high herbaceous communities; lower layers are in the shade). The typical light level was $6.39 \pm 0.06$, which corresponds to the conditions that favour hemi-scyophytes - plants of little-closed foliage forests. The light mode was statistically significantly different between the polygons $(\mathrm{F}=5.4, \mathrm{P}<0.001)$. The light regime in the park area after reconstruction was statistically significantly different from the regime in the untreated park area $(\mathrm{F}=646.7, \mathrm{P}<0.001)$. The lighting regime after the reconstruction was favourable to sub-heliophytes, and in the unreconstructed area the regime favoured hemi-scyophytes. The probability $<0.1$ of difference between the phytoindication estimate of light at a given site and the estimate obtained from a randomized sample from a list of species at the same extent range occurred in $20.1 \%$ and $19.1 \%$ of cases at polygons 1 and 2 (Fig. 1). This value is 34.3\% and $49.5 \%$ at polygons 3 and 4 . This probability correlates positively with the number of species $(r=0.26, \mathrm{P}<0.001)$. The proportion of hemicryptophytes in the plant community increases with increasing light regime $(\mathrm{r}=$ $0.36, \mathrm{P}<0.001)$, and the proportion of therophytes decreases $(\mathrm{r}=-0.35, \mathrm{P}$ $<0.001)$. This pattern is most pronounced for the untreated sites.

Tree canopy crown closure negatively correlated with grass height $(\mathrm{r}=-0.32, \mathrm{P}<0.001)$ and with herbaceous layer projective cover $(\mathrm{r}=$ $-0.16, \mathrm{P}=0.001)$. The correlation between grass height and herbaceous layer projective cover was statistically significantly positive $(\mathrm{r}=0.44, \mathrm{P}<$ 0.001 ). The tree canopy crown closure, grass height, and herbaceous layer projective cover were able to explain $86.0 \%$ of the phytoindication assessment of the lighting regime variation (Table 2). The regression coefficients indicated that the tree canopy crown closure, grass height, and herbaceous layer projective cover negatively affected the light regime. This pattern was common to the entire park plantation, but the patterns identified had their own specificity depending on the type of polygon. The positive regression coefficients for the Polygon $\times$ Crown closure predictor indicate that the rate of decrease in light intensity with increasing crown cover in polygons 1 and 2 was less than such for polygon 4 , which was considered the reference. This result can be illustrated graphically (Fig. 2). The pairwise correlation coefficients of the tree canopy crown closure and the phytoindication assessment of the lighting regime were statistically insignificant for polygons 1 and 2 (Fig. 3), whereas the pairwise coefficient for polygon 3 was greater in modulo than for polygon 4 $(\mathrm{P}<0.001)$. According to GLM results, the rate of change in light with changes in grass height did not differ between polygons 3 and 4 , whereas this relationship was weaker for polygons 1 and 2 . The pairwise correlation coefficients indicated a positive correlation between grass height and illumination for polygon 4 (Fig. 4). Obviously, taking into account the influence of other factors, which is carried out in the GLM procedure allows us to obtain an adequate assessment of the relationship between the indicators.

\section{Table 1}

Descriptive statistics of number of herbaceous plant species, tree canopy crown closure, grass height, herbaceous layer projective cover, and phytoindication assessment of the lighting regime of park plantation vegetation cover

\begin{tabular}{llrcc}
\hline \multicolumn{1}{c}{ Parameter } & \multicolumn{1}{c}{ Polygon } & \multicolumn{1}{c}{$\mathrm{x} \pm \mathrm{SE}$} & Minimum & Maximum \\
\hline & $1(\mathrm{~N}=105)$ & $9.79 \pm 0.18$ & 6 & 16 \\
Number of herba- & $2(\mathrm{~N}=105)$ & $11.02 \pm 0.24$ & 5 & 19 \\
ceous plant species & $3(\mathrm{~N}=105)$ & $8.69 \pm 0.14$ & 6 & 13 \\
& $4(\mathrm{~N}=105)$ & $7.40 \pm 0.26$ & 5 & 17 \\
& Total $(\mathrm{N}=420)$ & $9.22 \pm 0.12$ & 5 & 19 \\
\hline & $1(\mathrm{~N}=105)$ & $35.90 \pm 2.17$ & 0 & 70 \\
& $2(\mathrm{~N}=105)$ & $34.43 \pm 1.50$ & 0 & 75 \\
Tree canopy & $3(\mathrm{~N}=105)$ & $38.19 \pm 1.66$ & 10 & 80 \\
crown closure, \% & $4(\mathrm{~N}=105)$ & $72.81 \pm 1.67$ & 30 & 95 \\
& Total $(\mathrm{N}=420)$ & $45.33 \pm 1.18$ & 0 & 95 \\
\hline & $1(\mathrm{~N}=105)$ & $0.58 \pm 0.03$ & 0.00 & 1.3 \\
& $2(\mathrm{~N}=105)$ & $0.76 \pm 0.02$ & 0.30 & 1.4 \\
& $3(\mathrm{~N}=105)$ & $0.71 \pm 0.02$ & 0.15 & 1.2 \\
& $4(\mathrm{~N}=105)$ & $0.34 \pm 0.03$ & 0.10 & 1.1 \\
& $\mathrm{Total}(\mathrm{N}=420)$ & $0.60 \pm 0.01$ & 0.00 & 1.4 \\
\hline \multirow{4}{*}{ Grass height, $\mathrm{m}$} & $1(\mathrm{~N}=105)$ & $65.68 \pm 1.52$ & 25 & 100 \\
Herbaceous layer & $2(\mathrm{~N}=105)$ & $70.64 \pm 1.53$ & 35 & 100 \\
projective cover, & $3(\mathrm{~N}=105)$ & $70.50 \pm 2.27$ & 15 & 100 \\
\% & $4(\mathrm{~N}=105)$ & $60.69 \pm 2.60$ & 5 & 100 \\
& Total $(\mathrm{N}=420)$ & $66.88 \pm 1.03$ & 5 & 100 \\
\hline Phytoindication & $1(\mathrm{~N}=105)$ & $7.65 \pm 0.05$ & 6.3 & 8.75 \\
assessment of the & $2(\mathrm{~N}=105)$ & $7.19 \pm 0.06$ & 5.8 & 8.55 \\
lighting regime & $3(\mathrm{~N}=105)$ & $6.00 \pm 0.09$ & 4.4 & 8.20 \\
(Lc according to & $4(\mathrm{~N}=105)$ & $4.73 \pm 0.06$ & 3.8 & 6.63 \\
Didukh), scores & Total $(\mathrm{N}=420)$ & $6.39 \pm 0.06$ & 3.8 & 8.75 \\
\hline
\end{tabular}

\section{Table 2}

General linear model of the effect of the tree canopy crown closure, grass height, and herbaceous layer projective cover on the phytoindication assessment of the lighting regime (Radj2 $=0.86, \mathrm{~F}=198.0, \mathrm{P}<0.001$ )

\begin{tabular}{|c|c|c|c|c|c|}
\hline \multirow{2}{*}{ Predictors } & \multirow{2}{*}{$\begin{array}{l}\text { Level } \\
\text { of effect }\end{array}$} & \multicolumn{3}{|c|}{$\beta$-regression coefficient } & \multirow{2}{*}{$P$-level } \\
\hline & & $\mathrm{x} \pm \mathrm{SE}$ & $-95.0 \%$ & $+95.0 \%$ & \\
\hline Crown closure & - & $-0.20 \pm 0.09$ & -0.37 & -0.03 & 0.020 \\
\hline Grass height & - & $-0.28 \pm 0.09$ & -0.45 & -0.11 & 0.001 \\
\hline Projective cover & - & $-0.26 \pm 0.07$ & -0.39 & -0.13 & 0.001 \\
\hline Polygon & 1 & $0.74 \pm 0.11$ & 0.53 & 0.96 & 0.001 \\
\hline Polygon & 2 & $0.47 \pm 0.11$ & 0.24 & 0.69 & 0.001 \\
\hline Polygon & 3 & $0.41 \pm 0.09$ & 0.22 & 0.59 & 0.001 \\
\hline Polygon $\times$ Crown closure & 1 & $0.29 \pm 0.06$ & 0.16 & 0.41 & 0.001 \\
\hline Polygon $\times$ Crown closure & 2 & $0.40 \pm 0.08$ & 0.25 & 0.56 & 0.001 \\
\hline Polygon $\times$ Crown closure & 3 & $-0.81 \pm 0.08$ & -0.98 & -0.65 & 0.001 \\
\hline Polygon×Grass height & 1 & $-0.14 \pm 0.05$ & -0.23 & -0.05 & 0.002 \\
\hline Polygon $\times$ Grass height & 2 & $-0.17 \pm 0.07$ & -0.30 & -0.03 & 0.015 \\
\hline Polygon $\times$ Grass height & 3 & $-0.08 \pm 0.07$ & -0.22 & 0.05 & 0.241 \\
\hline Polygon $\times$ Projective cover & 1 & $-0.23 \pm 0.09$ & -0.40 & -0.05 & 0.013 \\
\hline Polygon $\times$ Projective cover & 2 & $-0.18 \pm 0.10$ & -0.39 & 0.02 & 0.080 \\
\hline Polygon $\times$ Projective cover & 3 & $-0.10 \pm 0.09$ & -0.28 & 0.07 & 0.251 \\
\hline $\begin{array}{l}\text { Crown closure } \times \\
\text { Grass height }\end{array}$ & - & $0.06 \pm 0.07$ & -0.07 & 0.19 & 0.343 \\
\hline $\begin{array}{l}\text { Crown closure } \times \\
\text { Projective cover }\end{array}$ & - & $-0.10 \pm 0.09$ & -0.28 & 0.08 & 0.275 \\
\hline $\begin{array}{l}\text { Grass height } \times \\
\text { Projective cover }\end{array}$ & - & $0.32 \pm 0.09$ & 0.13 & 0.50 & 0.001 \\
\hline
\end{tabular}

According to GLM results, the relationships between projective grass cover and light did not differ between polygons 3 and 4 . The relationship was weaker for polygons 1 and 2 . The pairwise correlation coefficients indicated a negative correlation for polygons 1,2 , and 3 and no correlation for polygon 4 (Fig. 5). The influence of grass height and density had a positive synergistic effect on the light regime. 

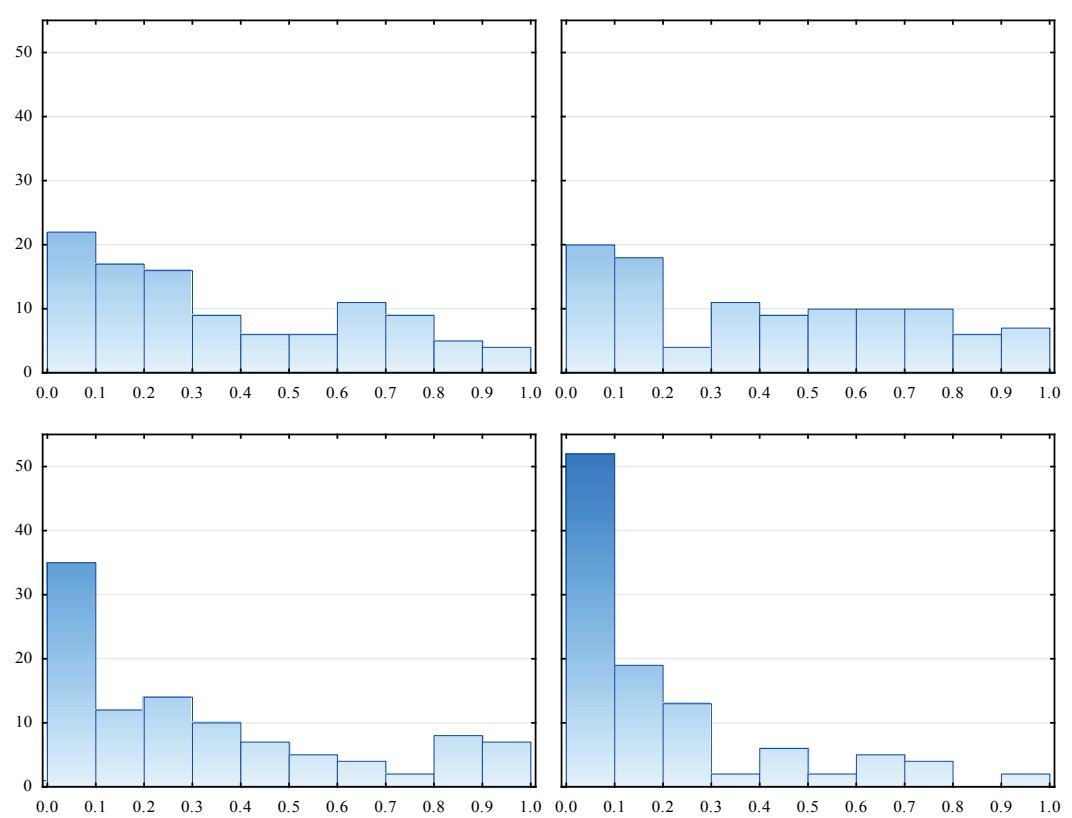

Fig. 1. The distribution histogram of probabilities of difference between observed phytoindication estimates and those obtained as a result of estimates for species populations, which are the result of random sampling from the total list of species in the polygon according to the permutation test results: the abscissa axis is the $\mathrm{P}$-value, the ordinate axis is the number of observations; a is polygon $1(\mathrm{~N}=105)$ $b$ is polygon $2(\mathrm{~N}=105)$, $\mathrm{c}$ is polygon $3(\mathrm{~N}=105)$, $\mathrm{d}$ is polygon $4(\mathrm{~N}=105)$
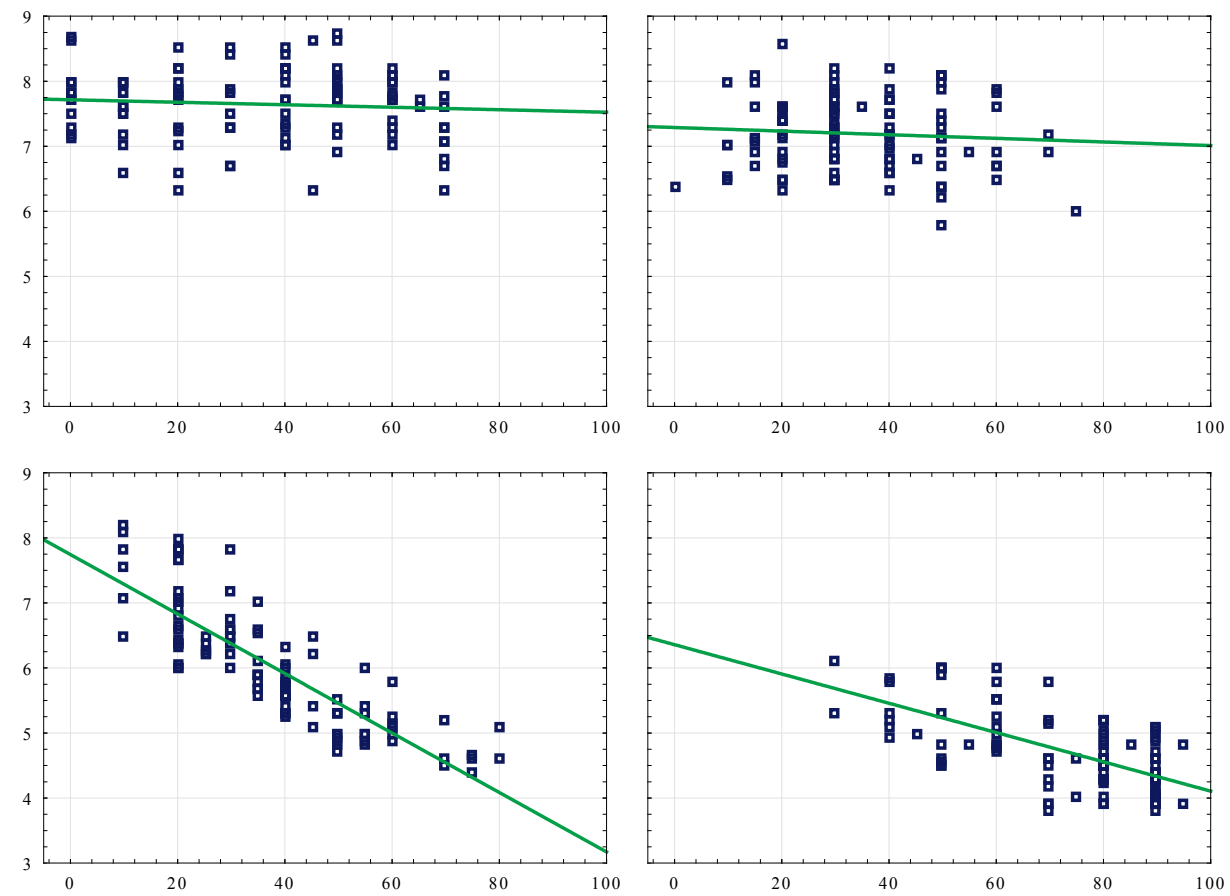

Fig. 2. The dependence of the phytoindication assessment of the light regime on the crown density of tree plants and shrubs: $\mathrm{X}$-axis is crown closeness, \%; Y-axis is the assessment of the light regime, points; a is polygon $1(\mathrm{~N}=105), \mathrm{b}$ is polygon $2(\mathrm{~N}=105)$, c is polygon $3(\mathrm{~N}=105), \mathrm{d}$ is polygon $4(\mathrm{~N}=105)$

\section{Discussion}

The ground vegetation is of great value as an indicator of the management impact on the structure and function of forests and park plantations (Halpern \& Spies, 1995; Brunet et al., 1996; Rédei et al., 2020; Oettel \& Lapin, 2021; Stefanovska et al., 2021). The trajectories of successional vegetation dynamics differ between forests after reconstruction and without reconstruction. The restoration procedures created areas favourable to the germination and growth of species adapted to high-light conditions and disturbed soils (Johnson \& Handel, 2015). The data obtained in our study indicate that the reconstruction of the park affected the number of vascular plant species. Changes in the light regime of the park plantation as a result of thinning of the canopy of tree plants and the destruction of the shrub layer created conditions for the growth and development of photophilic species of the herbaceous layer. These results are in agreement with findings that indicate that the soil and light conditions influence the species richness of ground vegetation depending on vegetation type (Härdtle et al., 2003). In humid forests, species richness has a strong positive correlation with soil moisture, while light conditions and nutrient supply mostly have no effect on species richness. In meso- and eutrophic forests, species richness is closely correlated with soil activity and base and nitrogen availability. Improving light conditions for terrestrial vegetation does not increase the number of typical forest species because most of them are shade-tolerant and have very limited light requirements. Species richness in acidophytic forests depends mainly on canopy closure and internal light conditions. Therefore, soil moisture, nutrient input, and light 
availability must be evaluated differently in terms of their influence on the number of terrestrial vegetation species and with respect to individual forest communities, as they vary with site conditions. If the relationship between species richness and environmental factors, such as soil conditions, is not analyzed for individual forest communities, but for the whole forest community, relationships may be found that do not help to explain the species richness of a particular forest community and thus have only limited utility for appropriate forest management recommendations (Härdtle et al., 2003). Our results also highlight the fact that the impact of park reconstruction is also superimposed on the specific characteristics of a particular park site.

The plant community transformations should also be considered in the context of changes in the information value of vegetation for phytoindication of ecological regimes. The widespread use of phytoindicator scales to resolve ecological problems raises the question of the overall reliability of the results obtained (Otýpková, 2009). The average values of
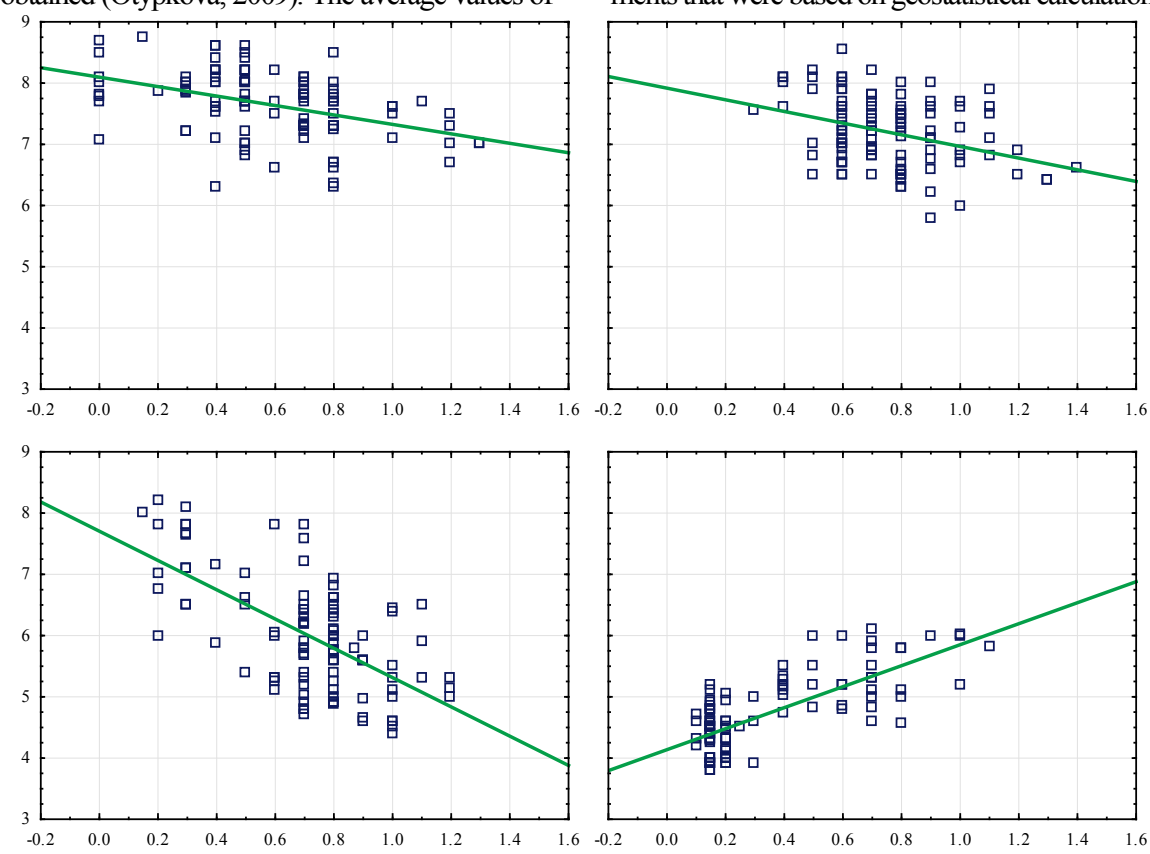

Fig. 3. The dependence of the phytoindication assessment of the light regime on the height of the grass stand: $\mathrm{X}$-axis is grass height, $\mathrm{m}$; $\mathrm{Y}$-axis is the assessment of the light regime, points; $\mathrm{a}$ is polygon $1(\mathrm{~N}=105), \mathrm{b}$ is polygon $2(\mathrm{~N}=105)$, c is polygon $3(\mathrm{~N}=105), \mathrm{d}$ is polygon $4(\mathrm{~N}=105)$
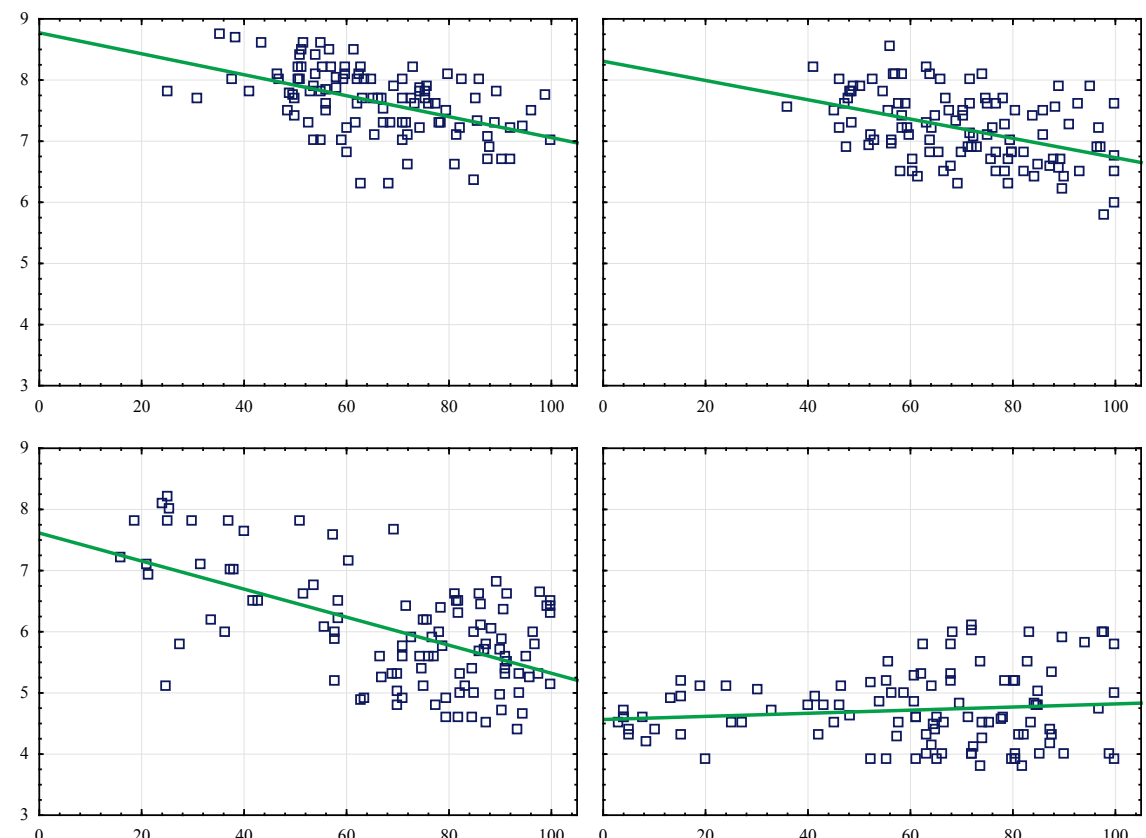

Fig. 4. The dependence of the phytoindication assessment of the light regime on the projective cover of grass stand:

$\mathrm{X}$-axis is the projective cover of herbage, $\%$; Y-axis is the assessment of the light regime, points; a is polygon $1(\mathrm{~N}=105)$, b is polygon $2(\mathrm{~N}=105)$, c is polygon $3(\mathrm{~N}=105), \mathrm{d}$ is polygon $4(\mathrm{~N}=105)$ 
The number of species in the geobotanical relevés affects the reliability of phytoindication estimates. When the number of species in the description is 15-20 and more, the method of phytoindication provides a generally adequate assessment of ecological regimes (Didukh, 2012). There is a point of view that there should not be less than 5 species in the description for sufficient accuracy of ecological assessments (Tsatsenkin, 1970). The conclusions should be taken into account as based on expert evaluations and such that have no sufficient statistical basis. Our studies show that the number of species on $3 \times 3$ meter sites was not less than 5 , which suggests sufficient reliability of the obtained phytoindication estimates.

There is a problem of logical circle (tautology) when trying to explain vegetation patterns using bioindication (Szymura et al., 2014). The problem arises from the fact that phytoindication estimates of environmental factors have two sources. These are the phytoindication values of individual species that indicate their ecological features and the composition of species in the geobotanical record from which the phytoindication assessment is made. The effect of retaining information on species composition and their similarity or difference compared to other compositions in the phytoindication assessment is called the "similarity problem" (Zelený \& Schaffers, 2012; Zhukov et al., 2018). To account for the problem of ecological similarity between species, a modification of this first step in the permutation test process is that randomization of species indicator values among species in the description is applied instead of randomization of the calculated mean indicator values (Zelený \& Schaffers, 2012). In our study, we aimed at a somewhat different task, namely to evaluate the specificity of indicative assessments at sites $3 \times 3 \mathrm{~m}$ in size compared to the polygon as a whole. In other words, we wanted to solve the issue of the reliability of phytoindication within the chosen spatial scale. The permutation test we proposed showed that the park reconstruction resulted in change in the vegetation cover so the level of specificity of individual sites decreased compared with the situation observed within the untreated polygons. This observation may be due to anthropogenic homogenization, which leads to the evening out of ecological conditions in the area of anthropogenic impact. The environmental homogenization as a result of reconstruction was accompanied by increase in the species diversity of the plant community due to increase in the number of photophilic species.

The permutation test also provides an indication of the reliability of phytoindication assessments. The reliability of phytoindication estimates in the context of the ability to indicate site-specific features of the ecological regime was found to decrease with an increase in species richness. Shelford's law of tolerance (Shelford, 1911, 1931) predicts that species in the optimum zone are the least sensitive to changes in environmental conditions. This explains the fact that the approach of a community to the optimum conditions for most species is followed by a decrease in its phytoindicator value. As an alternative hypothesis, we can consider the scenario of increase in the role of interspecific interactions with increase in the species diversity of the community. The diversity is a factor of community stability, and therefore independence from fluctuations in environmental conditions (Thébault \& Loreau, 2005; Zymaroieva et al., 2021). The phytoindication concept is based entirely on the ecological niche theory (Hutchinson, 1965). However, ecological niche theory is not the only concept that is applied to explain community structure. Neutrality theory also has considerable explanatory power (Hubbell, 2001; Hu et al., 2006; Adler et al., 2007; Etienne, 2009; Zhukov et al., 2019), especially at the detailed spatial level (Zhukov et al., 2018; Zhukov et al., 2019). The neutral effects are related to dispersal. The creation of new ecological space as a result of park reconstruction may be the reason for the advantage of neutral effects over the effects according to the ecological niche theory. Its consequence may also be decrease in the reliability of phytoindication estimates.

The reconstruction of the park led to decrease in crown density, resulting in increase in projective cover and height of vegetation cover. The effect of the mentioned ecological properties on the indication assessment of light is unidirectional: increase in crown density, height and projective cover of vegetation leads to decrease in light indicator values. The mentioned patterns were common for the park as a whole, while significant deviations from typical dependencies were observed as a result of the reconstruction. The role of the crown cover factor in structuring the herbaceous layer was most important in the untreated part of the park.
For the area after the reconstruction, crown cover was not important in the variability of the light regime. The most probable reason was the delayed development of vegetation cover after the abrupt anthropogenic transformation. The vegetation cover has not yet had time to adapt to the ecological conditions, which suddenly changed after the trimming of branches of tree plants and the removal of shrubs. The response of the light indicator to the effect of grass height in the reconstruction and untreated zones was opposite. In the reconstruction zone, the increase in height was associated with the decrease in the light level of the ecotope. The result quite predictably was that the higher grass stand was able to absorb more solar energy and had a greater ability to form shade. The trend of increasing light levels with increasing plant height is apparent in areas of the park without reconstruction. This pattern can be explained by the location of higher herbaceous plants in areas without tree vegetation, which are better supplied with light than the polygon as a whole.

Under reconstruction, the amount of light decreased with increasing projective cover of herbaceous vegetation. No such dependence was found in the untreated conditions. Thus, the leading driver of the light regime of the forest park plantation was crown closure. After reconstruction, the leading role in varying of the light regime transferred to the grass cover. Obviously, the return of the leading role of the crown closure in spatial variation of light regime should be considered as a marker in the process of vegetation recovery after reconstruction.

The vascular plants can be divided into life forms. The influence of environmental factors is different for different groups of plants. Among the main life forms, the highest level of relative species richness in the temperate climate zone is achieved by the hemicryptophytes (Raunkiaer, 1937). The proportion of phanerophytes is maximal in the humid tropics, the proportion of therophytes is maximal in the desert, and the proportion of hemicryptophytes is maximal in the dry grassland (Whittaker, 1960). Our results show that as the light regime increases in the plant community, the proportion of hemicryptophytes increases and the proportion of therophytes decreases. The hemicryptophytes in the temperate zone show a positive correlation with the light regime, while the inverse relationship was found for the therophytes (Shary et al., 2019).

The prospect of further research is to investigate the dependence of indicative reliability of the assessment of other environmental factors with the help of phytoindication depending on the number of species. In addition to the indication of traditional ecological factors it is of particular interest to clarify the question of the dynamics of hemeroby indicators as a result of park reconstruction.

\section{Conclusion}

The park reconstruction resulted in the increase in the number of photophilic herbaceous plant species. The phytoindication assessment of the light regime was an effective tool to assess the degree of transformation of the park plantation and the dynamics of vegetation cover after reconstruction. The proposed permutation test allowed us to demonstrate the possibility of using the phytoindication method at fine-scale spatial level, which is important for monitoring the state of green park plantations. The reconstruction led to homogenization of ecological conditions of particular parts of the park. The reliability of fine-scale assessments of phytoindication decreased with increase in species richness. The spatial organization of tree crowns was the leading factor in structuring of the herb layer in the untreated areas of the park. After reconstruction, the role of tree crowns decreased, which was due to the effect of delayed response of grass cover to abrupt changes in the state of the crown.

\section{References}

Adler, P. B., Seabloom, E. W., Borer, E. T., Hillebrand, H., Hautier, Y., Hector, A. Harpole, W. S., O’Halloran, L. R., Grace, J. B., Anderson, T. M., Bakker, J. D., Biederman, L. A., Brown, C. S., Buckley, Y. M., Calabrese, L. B., Chu, C.-J., Cleland, E. E., Collins, S. L., Cottingham, K. L., Yang, L. H. (2011). Productivity is a poor predictor of plant species richness. Science, 333(6050), 1750-1753. Adler, Peter B., HilleRislambers, J., \& Levine, J. M. (2007). A niche for neutrality. Ecology Letters, 10(2), 95-104. 
Akbari, H., Pomerantz, M., \& Taha, H. (2001). Cool surfaces and shade trees to reduce energy use and improve air quality in urban areas. Solar Energy, 70(3), 295-310.

Alasmary, Z., Todd, T., Hettiarachchi, G. M., Stefanovska, T., Pidlisnyuk, V., Roozeboom, K., Erickson, L., Davis, L., \& Zhukov, O. (2020). Effect of soil treatments and amendments on the nematode community under Miscanthus growing in a lead contaminated military site. Agronomy, 10(11), 1727.

Alexander, C., Moeslund, J. E., Bøcher, P. K., Arge, L., \& Svenning, J.-C. (2013). Airborne laser scanner (LiDAR) proxies for understory light conditions. Remote Sensing of Environment, 134, 152-161.

Anderson, M. C., \& Denmead, O. T. (1969). Short wave radiation on inclined surfaces in model plant communities. Agronomy Journal, 61(6), 867-872.

Angeler, D. G., Göthe, E., \& Johnson, R. K. (2013). Hierarchical dynamics of ecological communities: Do scales of space and time match? PLoS ONE, 8(7), e69174.

Austin, M. P. (1976). On non-linear species response models in ordination. Vegetatio, 33(1), 33-41.

Austin, M. P., Nicholls, A. O., \& Margules, C. R. (1990). Measurement of the realized qualitative niche: Environmental niches of five Eucalyptus species. Ecological Monographs, 60(2), 161-177.

Austin, M. P., Nicholls, A. O., Doherty, M. D., \& Meyers, J. A. (1994). Determining species response functions to an environmental gradient by means of a $\beta$ function. Journal of Vegetation Science, 5(2), 215.

Austin, Mike P. (2013). Vegetation and environment: discontinuities and continuities. In E. van der Maarel \& J. Franklin (Eds.), Vegetation Ecology (pp. 71-106). John Wiley \& Sons, Ltd, Oxford, UK.

Bartelheimer, M., \& Poschlod, P. (2016). Functional characterizations of Ellenberg indicator values - a review on ecophysiological determinants. Functional Ecology, 30(4), 506-516.

Bartels, S. F., \& Chen, H. Y. H. (2010). Is understory plant species diversity driven by resource quantity or resource heterogeneity? Ecology, 91(7), 1931-1938.

Battisti, A., Marini, L., Pitacco, A., \& Larsson, S. (2013). Solar radiation directly affects larval performance of a forest insect. Ecological Entomology, 38(6), $553-559$.

Bjerke, T., Østdahl, T., Thrane, C., \& Strumse, E. (2006). Vegetation density of urban parks and perceived appropriateness for recreation. Urban Forestry \& Urban Greening, 5(1), 35-44.

Bode, C. A., Limm, M. P., Power, M. E., \& Finlay, J. C. (2014). Subcanopy solar radiation model: Predicting solar radiation across a heavily vegetated landscape using LiDAR and GIS solar radiation models. Remote Sensing of Environment, 154, 387-397.

Brunet, J., Falkengren-Grerup, U., \& Tyler, G. (1996). Herb layer vegetation of south Swedish beech and oak forests - effects of management and soil acidity during one decade. Forest Ecology and Management, 88(3), 259-272.

Brygadyrenko, V. V. (2015). Influence of tree crown density and density of the herbaceous layer on the structure of litter macrofauna of deciduous forests of Ukraine's steppe zone. Visnyk of Dnipropetrovsk University, Biology, Ecology, 23(2), 134-148.

Brygadyrenko, V. V. (2016). Evaluation of ecological niches of abundant species of Poecilus and Pterostichus (Coleoptera: Carabidae) in forests of the steppe zone of Ukraine. Entomologica Fennica, 27(2), 81-100.

Buzuk, G. N. (2017). Phytoindication with ecological scales and regression analysis: environmental index. Bulletin of Pharmacy, 2(76), 31-37.

Chaplygina, A. B., Savynska, N. O., \& Brygadyrenko, V. V. (2018). Trophic links of the spotted flycatcher, Muscicapa striata, in transformed forest ecosystems of North-Eastern Ukraine. Baltic Forestry, 24(2), 304-312.

Chocholoušková, Z., \& Pyšek, P. (2003). Changes in composition and structure of urban flora over 120 years: a case study of the city of Plzeň. Flora - Morphology, Distribution, Functional Ecology of Plants, 198(5), 366-376.

Currie, D. J. (1991). Energy and large-scale patterns of animal- and plant-species richness. The American Naturalist, 137(1), 27-49.

Deutz, P., Baxter, H., Gibbs, D., Mayes, W. M., \& Gomes, H. I. (2017). Resource recovery and remediation of highly alkaline residues: A political-industrial ecology approach to building a circular economy. Geoforum, 85, 336-344.

Didukh, Y. P. (2011). The ecological scales for the species of Ukrainian flora and their use in synphytoindication. Phytosociocenter, Kyiv.

Didukh, Y. P. (2012). Osnovy bioindykatsii [Fundamentals of bioindication] (D. M. Grodzinski (ed.)). Naukova Dumka, Kyiv (in Ukranian).

Diekmann, M. (1995). Use and improvement of Ellenberg's indicator values in deciduous forests of the Boreo-nemoral zone in Sweden. Ecography, 18(2), $178-189$.

Diekmann, M. (2003). Species indicator values as an important tool in applied plant ecology - A review. Basic and Applied Ecology, 4(6), 493-506.

Dimoudi, A., \& Nikolopoulou, M. (2003). Vegetation in the urban environment: microclimatic analysis and benefits. Energy and Buildings, 35(1), 69-76.

Dormann, C. F., Bagnara, M., Boch, S., Hinderling, J., Janeiro-Otero, A., Schäfer, D., Schall, P., \& Hartig, F. (2020). Plant species richness increases with light availability, but not variability, in temperate forests understorey. BMC Ecology, 20(1), 43.
Dray, S., \& Dufour, A. B. (2007). The ade4 package: Implementing the duality diagram for ecologists. Journal of Statistical Software, 22(4), 1-20.

Duarte, D. H. S., Shinzato, P., Gusson, C. dos S., \& Alves, C. A. (2015). The impact of vegetation on urban microclimate to counterbalance built density in a subtropical changing climate. Urban Climate, 14, 224-239.

Dyderski, M. K., Wrońska-Pilarek, D., \& Jagodziński, A. M. (2017). Ecological lands for conservation of vascular plant diversity in the urban environment. Urban Ecosystems, 20(3), 639-650.

Dzwonko, Z. (2001). Assessment of light and soil conditions in ancient and recent woodlands by Ellenberg indicator values. Journal of Applied Ecology, 38(5), 942-951.

Ellenberg, H. (1979). Zeigerwerte der Gefisspflanzen Mitteleuropas (2nd ed.). Scripta Geobotanica, Göttingen.

Ellenberg, H., Weber, H. E., Dull, R., Wirth, V., Werner, W., \& Paulissen, D. (1991). Zeigerwerte von Pflanzen in Mitteleuropa. Scripta Geobotanica, 18, 1-248.

Englund, S. R., O’Brien, J. J., \& Clark, D. B. (2000). Evaluation of digital and film hemispherical photography and spherical densiometry for measuring forest light environments. Canadian Journal of Forest Research, 30(12), 1999-2005.

Ertsen, A. C. D., Alkemade, J. R. M., \& Wassen, M. J. (1998). Calibrating Ellenberg indicator values for moisture, acidity, nutrient availability and salinity in the Netherlands. Plant Ecology, 135, 113-124.

Etienne, R. S. (2009). Improved estimation of neutral model parameters for multiple samples with different degrees of dispersal limitation. Ecology, 90(3), 847-852.

Ewald, J. (2003). The sensitivity of Ellenberg indicator values to the completeness of vegetation relevés. Basic and Applied Ecology, 4(6), 507-513.

Figueroa, J. A., Castro, S. A., Reyes, M., \& Teillier, S. (2018). Urban park area and age determine the richness of native and exotic plants in parks of a Latin American city: Santiago as a case study. Urban Ecosystems, 21(4), 645-655.

Gaujour, E., Amiaud, B., Mignolet, C., \& Plantureux, S. (2012). Factors and processes affecting plant biodiversity in permanent grasslands. A review. Agronomy for Sustainable Development, 32(1), 133-160.

Georgi, J. N., \& Dimitriou, D. (2010). The contribution of urban green spaces to the improvement of environment in cities: Case study of Chania, Greece. Building and Environment, 45(6), 1401-1414.

Godefroid, S. (2001). Temporal analysis of the Brussels flora as indicator for changing environmental quality. Landscape and Urban Planning, 52(4), 203-224.

Godefroid, S., \& Ricotta, C. (2018). Alien plant species do have a clear preference for different land uses within urban environments. Urban Ecosystems, 21(6), 1189-1198.

Goncharenko, I. V., \& Yatsenko, H. M. (2020). Phytosociological study of the forest vegetation of Kyiv urban area (Ukraine). Hacquetia, 19(1), 99-126.

Grant, R. H. (1997). Partitioning of biologically active radiation in plant canopies. International Journal of Biometeorology, 40(1), 26-40.

Grime, J. P., Mason, G., Curtis, A. V., Rodman, J., \& Band, S. R. (1981). A comparative study of germination characteristics in a local flora. The Journal of Ecology, 69(3), 1017.

Grimm, N. B., Faeth, S. H., Golubiewski, N. E., Redman, C. L., Wu, J., Bai, X., \& Briggs, J. M. (2008). Global change and the ecology of cities. In Science (Vol. 319 , Issue 5864 , pp. 756-760).

Halpern, C. B., \& Spies, T. A. (1995). Plant species diversity in natural and managed forests of the Pacific Northwest. Ecological Applications, 5(4), 913-934.

Hamada, S., \& Ohta, T. (2010). Seasonal variations in the cooling effect of urban green areas on surrounding urban areas. Urban Forestry \& Urban Greening, 9(1), 15-24.

Hannerz, M., \& Hånell, B. (1997). Effects on the flora in Norway spruce forests following clearcutting and shelterwood cutting. Forest Ecology and Management, 90(1), 29-49.

Härdtle, W., von Oheimb, G., \& Westphal, C. (2003). The effects of light and soil conditions on the species richness of the ground vegetation of deciduous forests in northern Germany (Schleswig-Holstein). Forest Ecology and Management, 182(1-3), 327-338.

Harrison, S. (2020). Plant community diversity will decline more than increase under climatic warming. Philosophical Transactions of the Royal Society B: Biological Sciences, 375(1794), 0106.

Hu, X. S., He, F., \& Hubbell, S. P. (2006). Neutral theory in macroecology and population genetics. Oikos, 113(3), 548-556.

Hubbell, S. P. (2001). The unified neutral theory of biodiversity and biogeography. Princeton University Press, New Jersey, USA, Princeton.

Huisman, J., Olff, H., \& Fresco, L. F. M. (1993). A hierarchical set of models for species response analysis. Journal of Vegetation Science, 4(1), 37-46.

Hutchinson, G. E. (1965). The niche: an abstractly inhabited hypervolume. The ecological theatre and the evolutionary play. Yale University Press, New Haven.

Isbell, F., Adler, P. R., Eisenhauer, N., Fornara, D., Kimmel, K., Kremen, C., Letourneau, D. K., Liebman, M., Polley, H. W., Quijas, S., \& Scherer-Lorenzen, M. (2017). Benefits of increasing plant diversity in sustainable agroecosystems. Journal of Ecology, 105(4), 871-879.

Jennings, S. (1999). Assessing forest canopies and understorey illumination: Canopy closure, canopy cover and other measures. Forestry, 72(1), 59-74. 
Johnson, L. R., \& Handel, S. N. (2015). Restoration treatments in urban park forests drive long-term changes in vegetation trajectories. Ecological Applications, 14 2063.1.

Jones, H. G., Archer, N., Rotenberg, E., \& Casa, R. (2003). Radiation measurement for plant ecophysiology. Journal of Experimental Botany, 54(384), 879-889.

Kaplan, R., Kaplan, S., \& Brown, T. (1989). Environmental preference. Environment and Behavior, 21(5), 509-530.

Kyereh, B., Swaine, M. D., \& Thompson, J. (1999). Effect of light on the germination of forest trees in Ghana. Journal of Ecology, 87(5), 772-783.

Lawesson, J. E., \& Oksanen, J. (2002). Niche characteristics of Danish woody species as derived from coenoclines. Journal of Vegetation Science, 13(2), 279-290.

Li, Y. (2020). Reconstruction of plant space in the urban park guided by visual experience of tourists - A case study of the Ait park afforestation design in Fuzhou. In: Shoji, H., Koyama, S., Kato, T., Muramatsu, K., Yamanaka, T., Lévy, P., Chen, K., \& Lokman, A. (Eds.). Proceedings of the 8th International Conference on Kansei Engineering and Emotion Research. Springer, Singapore. Pp. 349-358

Li, Z., Chen, D., Cai, S., \& Che, S. (2018). The ecological services of plant communities in parks for climate control and recreation - A case study in Shanghai, China. PLoS One, 13(4), e0196445.

Lin, T.-P., Matzarakis, A., \& Hwang, R.-L. (2010). Shading effect on long-term outdoor thermal comfort. Building and Environment, 45(1), 213-221.

Lososová, Z., Horsák, M., Chytrý, M., Čejka, T., Danihelka, J., Fajmon, K., Hájek, O., Juřičková, L., Kintrová, K., Láníková, D., Otýpková, Z., Rehořek, V., \& Tichý, L. (2011). Diversity of Central European urban biota: Effects of humanmade habitat types on plants and land snails. Journal of Biogeography, 38(6), $1152-1163$.

Maltsev, Y. I., Didovich, S. V., \& Maltseva, I. A. (2017). Seasonal changes in the communities of microorganisms and algae in the litters of tree plantations in the steppe zone. Eurasian Soil Science, 50(8), 935-942.

Maltsev, Y., \& Maltseva, I. (2018). The influence of forest-forming tree species on diversity and spatial distribution of algae in forest litter. Folia Oecologica, 45(2), $72-81$.

Maltseva, I. A., Maltsev, Y. I., \& Solonenko, A. N. (2017). Soil algae of the oak groves of the steppe zone of Ukraine. International Journal on Algae, 19(3), 215-226.

Marcenò, C., \& Guarino, R. (2015). A test on Ellenberg indicator values in the Mediterranean evergreen woods (Quercetea ilicis). Rendiconti Lincei, 26(3), 345-356.

Martens, S. N., Breshears, D. D., \& Meyer, C. W. (2000). Spatial distributions of understory light along the grassland/forest continuum: Effects of cover, height, and spatial pattern of tree canopies. Ecological Modelling, 126(1), 79-93.

Matsala, M., Bilous, A., Feshchenko, R., Matiashuk, R., Bilous, S., \& Kovbasa, Y. (2021). Spatial and compositional structure of European oak urban forests in Kyiv city, Ukraine. Journal of Forest Science, 67(3), 143-153.

Musselman, K. N., Margulis, S. A., \& Molotch, N. P. (2013). Estimation of solar direct beam transmittance of conifer canopies from airborne LiDAR. Remote Sensing of Environment, 136, 402-415.

Oettel, J., \& Lapin, K. (2021). Linking forest management and biodiversity indicators to strengthen sustainable forest management in Europe. Ecological Indicators, 122,107275

Otýpková, Z. (2009). The influence of sample plot size on evaluations with Ellenberg indicator values. Biologia, 64(6), 1123-1128.

Parsons, R. (1995). Conflict between ecological sustainability and environmental aesthetics: Conundrum, canärd or curiosity. Landscape and Urban Planning, 32(3), 227-244.

Peng, S., Zhao, C., \& Xu, Z. (2014). Modeling spatiotemporal patterns of understory light intensity using airborne laser scanner (LiDAR). ISPRS Joumal of Photogrammetry and Remote Sensing, 97, 195-203.

Pignatti, S., Bianco, P., Fanelli, G., Guarino, R., Petersen, J., \& Tescarollo, P. (2001). Reliability and effectiveness of Ellenberg's indices in checking flora and vegetation changes induced by climatic variations. In: Walther, G. R., Burga, C. A., \& Edwards, P. J. (Eds.). "Fingerprints" of climate change. Springer US, Boston. Pp. 281-304.

Putchkov, A. V., Brygadyrenko, V. V., \& Markina, T. Y. (2019). Ground beetles of the tribe Carabini (Coleoptra, Carabidae) in the main megapolises of Ukraine. Vestnik Zoologii, 53(1), 3-12

Qin, Z., Li, Z., Cheng, F., Chen, J., \& Liang, B. (2014). Influence of canopy structural characteristics on cooling and humidifying effects of Populus tomentosa community on calm sunny summer days. Landscape and Urban Planning, 127, 75-82.

Raunkiaer, C. (1937). Plant life forms. Clarendon Press, Oxford.

Rédei, T., Csecserits, A., Lhotsky, B., Barabás, S., Kröel-Dulay, G., Ónodi, G., \& Botta-Dukát, Z. (2020). Plantation forests cannot support the richness of forest specialist plants in the forest-steppe zone. Forest Ecology and Management, $461,117964$.

Rosenzweig, M. L. (1995). Species diversity in space and time. Cambridge University Press, Cambridge.
Sakai, T., \& Akiyama, T. (2005). Quantifying the spatio-temporal variability of net primary production of the understory species, Sasa senanensis, using multipoint measuring techniques. Agricultural and Forest Meteorology, 134, 60-69.

Salinitro, M., Alessandrini, A., Zappi, A., \& Tassoni, A. (2019). Impact of climate change and urban development on the flora of a southern european city: Analysis of biodiversity change over a 120-year period. Scientific Reports, 9(1), 9464.

Samec, P., Volánek, J., Kučera, M., \& Cudlín, P. (2021). Effect of soil diversity on forest plant species abundance: A case study from central-european highlands. Forests, 12(5), 534.

Schaffers, A. P., \& Sýkora, K. V. (2000). Reliability of Ellenberg indicator values for moisture, nitrogen and soil reaction: A comparison with field measurements. Journal of Vegetation Science, 11(2), 225-244.

Sercu, B. K., Baeten, L., van Coillie, F., Martel, A., Lens, L., Verheyen, K., \& Bonte, D. (2017). How tree species identity and diversity affect light transmittance to the understory in mature temperate forests. Ecology and Evolution, 7(24), 10861-10870.

Shahidan, M. F., Shariff, M. K. M., Jones, P., Salleh, E., \& Abdullah, A. M. (2010). A comparison of Mesua ferrea L. and Hura crepitans L. for shade creation and radiation modification in improving thermal comfort. Landscape and Urban Planning, 97(3), 168-181.

Shary, P. A., Sharaya, L. S., Ivanova, A. V., Kostina, N. V., \& Rosenberg, G. S (2019). Comparative analysis of the species richness of life forms of vascular plants in the Middle Volga. Contemporary Problems of Ecology, 12(4), 310-320.

Shashua-Bar, L., Tsiros, I. X., \& Hoffman, M. E. (2010). A modeling study for evaluating passive cooling scenarios in urban streets with trees. Case study: Athens, Greece. Building and Environment, 45(12), 2798-2807.

Shekhovtseva, O. G., \& Mal'tseva, I. A. (2015). Physical, chemical, and biological properties of soils in the city of Mariupol, Ukraine. Eurasian Soil Science, 48(12), 1393-1400.

Shelford, V. E. (1911). Ecological succession. I. Stream fishes and the method of physiographic analysis. The Biological Bulletin, 21(1), 9-35.

Shelford, V. E. (1931). Some concepts of bioecology. Ecology, 12(3), 455- 467.

Stefanovska, T., Skwiercz, A., Zouhar, M., Pidlisnyuk, V., \& Zhukov, O. (2021). Plant-feeding nematodes associated with Miscanthus $\times$ giganteus and their use as potential indicators of the plantations' state. International Journal of Environmental Science and Technology, 18(1), 57-72.

Storch, D., Bohdalková, E., \& Okie, J. (2018). The more-individuals hypothesis revisited: The role of community abundance in species richness regulation and the productivity-diversity relationship. Ecology Letters, 21(6), 920-937.

Strumse, E. (1994a). Environmental attributes and the prediction of visual preferences for agrarian landscapes in Western Norway. Journal of Environmental Psychology, 14(4), 293-303.

Strumse, E. (1994b). Perceptual dimensions in the visual preferences for agrarian landscapes in Western Norway. Journal of Environmental Psychology, 14(4), 281-292.

Szymura, T. H., Szymura, M., \& Macioł, A. (2014). Bioindication with Ellenberg's indicator values: A comparison with measured parameters in Central European oak forests. Ecological Indicators, 46, 495-503.

ter Braak, C. J. F., \& Looman, C. W. N. (1986). Weighted averaging, logistic regression and the Gaussian response model. Vegetatio, 65(1), 3-11.

Thébault, E., \& Loreau, M. (2005). Trophic interactions and the relationship between species diversity and ecosystem stability. The American Naturalist, 166(4) E95-E114.

Tsai, H.-C., Chiang, J.-M., McEwan, R. W., \& Lin, T.-C. (2018). Decadal effects of thinning on understory light environments and plant community structure in a subtropical forest. Ecosphere, 9(10), e02464.

Tsatsenkin, I. A. (1970). Ecological assessment of forage lands of the Carpathians and Balkans according to the vegetation cover. All-Union Scientific Research Institute of Fodder named after V. P. Williams, Moscow.

Tudoroiu, M., Genesio, L., Gioli, B., Schume, H., Knohl, A., Brümmer, C., \& Miglietta, F. (2018). Solar dimming above temperate forests and its impact on loca climate. Environmental Research Letters, 13(6), 64014.

Van der Zande, D., Stuckens, J., Verstraeten, W. W., Mereu, S., Muys, B., \& Coppin, P. (2011). 3D modeling of light interception in heterogeneous forest canopies using ground-based LiDAR data. International Journal of Applied Earth Observation and Geoinformation, 13(5), 792-800.

Van der Zande, D., Stuckens, J., Verstraeten, W. W., Muys, B., \& Coppin, P. (2010). Assessment of light environment variability in broadleaved forest canopies using terrestrial laser scanning. Remote Sensing, 2(6), 1564-1574.

Von Arx, G., Dobbertin, M., \& Rebetez, M. (2012). Spatio-temporal effects of forest canopy on understory microclimate in a long-term experiment in Switzerland. Agricultural and Forest Meteorology, 166-167, 144-155.

Wamelink, G. W. W., ter Braak, C. J. F., \& van Dobben, H. F. (2003). Changes in large-scale patterns of plant biodiversity predicted from environmental economic scenarios. Landscape Ecology, 18(5), 513-527.

Westhoff, V., \& Van Der Maarel, E. (1978). The Braun-Blanquet approach. In: Whittaker, R. H. (Ed.). Classification of plant communities. Springer Netherlands, Dordrecht. Pp. 287-399. 
Whittaker, R. H. (1960). Vegetation of the Siskiyou Mountains, Oregon and California. Ecological Monographs, 30(3), 279-338.

Wildi, O. (2016). Why mean indicator values are not biased. Journal of Vegetation Science, $27(1), 40-49$

Xu, H., Cao, M., Wu, Y., Cai, L., Cao, Y., Wu, J., Lei, J., Le, Z., Ding, H., \& Cui, P. (2016). Disentangling the determinants of species richness of vascular plants and mammals from national to regional scales. Scientific Reports, 6(1), 21988.

Xue, F., Gou, Z., \& Lau, S. (2017a). The green open space development model and associated use behaviors in dense urban settings: Lessons from Hong Kong and Singapore. Urban Design International, 22(4), 287-302.

Xue, F., Gou, Z., \& Lau, S. S. Y. (2017b). Green open space in high-dense Asian cities: Site configurations, microclimates and users' perceptions. Sustainable Cities and Society, 34, 114-125.

Zavala, M. A., Angulo, Ó., Bravo de la Parra, R., \& López-Marcos, J. C. (2007). An analytical model of stand dynamics as a function of tree growth, mortality and recruitment: The shade tolerance-stand structure hypothesis revisited. Journal of Theoretical Biology, 244(3), 440-450.

Zavitkovski, J. (1976). Ground vegetation biomass, production, and efficiency of energy utilization in some Northern Wisconsin forest ecosystems. Ecology, 57(4), 694-706.

Zelený, D., \& Schaffers, A. P. (2012). Too good to be true: Pitfalls of using mean Ellenberg indicator values in vegetation analyses. Journal of Vegetation Science, 23(3), 419-431.

Zhang, Z., Lv, Y., \& Pan, H. (2013). Cooling and humidifying effect of plant communities in subtropical urban parks. Urban Forestry and Urban Greening, 12(3), 323-329.
Zhukov, A. V., Kunakh, O. N., Dubinina, Y. Y., \& Ganzha, D. S. (2018). Application of $\beta$-function in phytoindication to account for species response curves asymmetry. Acta Biologica Sibirica, 4(2), 32.

Zhukov, O. V., Kunah, O. M., Dubinina, Y. Y., Fedushko, M. P., Kotsun, V. I., Zhukova, Y. O., \& Potapenko, O. V. (2019). Tree canopy affects soil macrofauna spatial patterns on broad- and meso-scale levels in an Eastern European poplarwillow forest in the floodplain of the River Dnipro. Folia Oecologica, 46(2), $101-114$.

Zhukov, O., Kunah, O., Dubinina, Y., \& Novikova, V. (2018). The role of edaphic and vegetation factors in structuring beta diversity of the soil macrofauna community of the Dnipro river arena terrace. Ekologia (Bratislava), 37(4), 301-327.

Zhukov, O., Kunah, O., Dubinina, Y., Ganga, D., \& Zadorozhnaya, G. (2017). Phylogenetic diversity of plant metacommunity of the dnieper river arena terrace within the "Dnieper-Orilskiy" Nature Reserve. Ekologia (Bratislava), 36(4), 352-365.

Zhukov, O., Kunah, O., Dubinina, Y., Zhukova, Y., \& Ganzha, D. (2019). The effect of soil on spatial variation of the herbaceous layer modulated by overstorey in an Eastem European poplar-willow forest. Ekologia (Bratislava), 38(3), 253-272.

Zhukov, O., Kunah, O., Fedushko, M., Babchenko, A., \& Umerova, A. (2021). Temporal aspect of the terrestrial invertebrate response to moisture dynamic in technosols formed after reclamation at a post-mining site in Ukrainian steppe drylands. Ekológia (Bratislava), 40(2), 178-188.

Zhukov, O., Yorkina, N., Budakova, V., \& Kunakh, O. (2021). Terrain and tree stand effect on the spatial variation of the soil penetration resistance in Urban Park. International Journal of Environmental Studies, 1-17.

Zymaroieva, A., Zhukov, O., Fedoniuk, T., Pinkina, T., \& Hurelia, V. (2021). The relationship between landscape diversity and crops productivity: Landscape scale study. Journal of Landscape Ecology, 14(1), 39-58. 